\title{
Toxoplasma gondii in domiciled dogs and cats in urban areas of Brazil: risk factors and spatial distribution
}

Igor Falco Arruda ${ }^{1}$, Patricia Riddell Millar ${ }^{1,2, *}$, Alynne da Silva Barbosa ${ }^{1,2}$, Luiz Claudio de Souza Abboud ${ }^{3}$, Izabel Cristina dos Reis ${ }^{4}$, Alex Sander da Cruz Moreira ${ }^{1}$, Mariana Pedrosa de Paula Guimarães ${ }^{1}$ and Maria Regina Reis Amendoeira ${ }^{1}$

${ }^{1}$ Laboratório de Toxoplasmose e outras Protozooses, Instituto Oswaldo Cruz/Fiocruz, Av. Brasil, 4365-Manguinhos, 21040-900 Rio de Janeiro, Brazil

${ }^{2}$ Departamento de Microbiologia e Parasitologia, Instituto Biomédico/Universidade Federal Fluminense, Rua Professor Hernani Melo, 101/212a-São Domingos, 24210-130 Niterói, Brazil

${ }^{3}$ Instituto Municipal de Medicina Veterinária Jorge Vaitsman, SUBVISA/Secretaria Municipal de Saúde, Av. Bartolomeu de Gusmão, 1120-São Cristóvão, 20941-160 Rio de Janeiro, Brazil

${ }^{4}$ Laboratório de Mosquitos Transmissores de Hematozoários, Instituto Oswaldo Cruz/Fiocruz, Av. Brasil, 4365-Manguinhos, 21040-900 Rio de Janeiro, Brazil

Received 30 December 2020, Accepted 1 June 2021, Published online 8 July 2021

\begin{abstract}
Toxoplasma gondii is a highly prevalent zoonotic parasite in Brazil capable of infecting mammals and birds. The increase in the urban populations of pets and the narrowing of the human-animal relationship can facilitate the transmission of important public health zoonoses, such as toxoplasmosis. This study aimed to evaluate the frequency and spatial distribution of $T$. gondii infection and its risk factors in domiciled dogs and cats attended at the Jorge Vaitsman Institute, Rio de Janeiro. Serum samples from $400 \mathrm{dogs}$ and 272 cats were evaluated by an indirect fluorescent antibody test (IFAT) for IgG anti- $T$. gondii antibodies. Epidemiological questionnaires were used to interview the animals' owners to identify risk factors for infection. Of the total, 34\% (136/400) of dogs and 8.1\% (22/272) of cats had anti-T. gondii antibodies. Breed (OR: 2.10-95\%, CI 1.27-3.46) was a risk factor for dogs, while sex (OR: 3.40-95\%, CI 1.10-10.52) and homemade food consumption (OR: 8.49-95\%, CI 2.48-29.05) were risk factors for cats. Offal consumption was considered a risk factor for both species evaluated (OR: 2.74-95\%, CI 1.38-5.43 for dogs; OR: 7.66-95\%, CI 1.24-47.29 for cats). The spatial analysis showed that $T$. gondii seropositive animals were widely distributed in the metropolitan region of Rio de Janeiro state, with a concentration observed mainly in the west and north zones of Rio de Janeiro city. The results emphasize the importance of adopting prophylactic measures to control T. gondii transmission in domiciled dogs and cats in Rio de Janeiro, contributing positively to public health.
\end{abstract}

Key words: Toxoplasmosis, Companion animals, Serology, Rio de Janeiro metropolitan region.

Résumé - Toxoplasma gondii chez les chiens et les chats domiciliés dans des zones urbaines du Brésil : facteurs de risque et répartition spatiale. Toxoplasma gondii est un parasite zoonotique très répandu au Brésil, capable d'infecter les mammifères et les oiseaux. L'augmentation des populations urbaines d'animaux de compagnie et le rétrécissement de la relation homme-animal peuvent faciliter la transmission de zoonoses importantes pour la santé publique, telles que la toxoplasmose. Cette étude visait à évaluer la fréquence et la distribution spatiale de l'infection à $T$. gondii et ses facteurs de risque chez les chiens et les chats domiciliés qui ont fréquenté l'Institut Jorge Vaitsman de Rio de Janeiro. Des échantillons de sérum de 400 chiens et 272 chats ont été évalués par un test d'immunofluorescence indirecte (IFAT) pour les anticorps IgG anti-T. gondii. Des questionnaires épidémiologiques ont été appliqués aux propriétaires des animaux pour identifier les facteurs de risque d'infection. Sur le total, $34 \%(136 / 400)$ des chiens et 8,1\% (22/272) des chats avaient des anticorps anti- $T$. gondii. La race (OR : 2,10-95\%, IC 1,27-3,46) était un facteur de risque pour les chiens, tandis que le sexe (OR : 3,40-95\%, IC 1,10-10,52) et la consommation d'aliments faits maison (OR : 8,49-95\% IC 2,48-29,05) l'étaient pour les chats. La consommation d'abats a été considérée comme un facteur de risque pour les deux espèces évaluées (OR : 2,74-95 \%, IC 1,38-5,43 pour les chiens; OR : 7,66-95 \%, IC 1,24-47,29 pour les chats). L'analyse spatiale a montré que les animaux séropositifs pour $T$. gondii étaient largement répartis dans la région métropolitaine de l'État de Rio de Janeiro, avec une concentration observée principalement dans les zones ouest et nord de la ville de Rio de Janeiro. Les résultats soulignent l'importance d'adopter des mesures prophylactiques pour contrôler la transmission de $T$. gondii chez les chiens et les chats domiciliés à Rio de Janeiro, contribuant positivement à la santé publique.

*Corresponding author: patríciariddell@id.uff.br

This is an Open Access article distributed under the terms of the Creative Commons Attribution License (https://creativecommons.org/licenses/by/4.0), which permits unrestricted use, distribution, and reproduction in any medium, provided the original work is properly cited. 


\section{Introduction}

The protozoan Toxoplasma gondii is a globally distributed parasite capable of infecting homeothermic animals [19, 82]. Felids, including domestic cats, are definitive hosts because they are able to spread oocysts in the environment through feces, only in the days following the first infection [20, 53]. High humidity and temperatures above $30{ }^{\circ} \mathrm{C}$ favor the sporulation and maintenance of the oocysts in the environment [85]. However, high temperatures above $60{ }^{\circ} \mathrm{C}$ are able to inactivate T. gondii oocysts and cysts, the major parasite structures related to transmission for their hosts $[22,28]$. For humans, the main transmission routes are the ingestion of raw or undercooked meat containing tissue cysts, and contaminated raw food and water with sporulated oocysts, or transplacental transmission [27]. In the urban context, domestic cats are considered the key host in the epidemiology of infection, as they are responsible for contamination of the environment shared with humans $[17,29]$. Domestic dogs, as well as other mammals, including humans, and birds, are $T$. gondii intermediate hosts. The diet is an important factor for infection by $T$. gondii in domestic dogs and cats $[25,29]$. The supply of leftovers, homemade food, and offal for these animals, especially dogs, may indicate possible sources of infection shared with humans.

In Brazil, there is high genetic diversity of $T$. gondii strains, including highly virulent clonal and atypical genotypes, isolated from different species of hosts [21, 23, 50, 59, 60, 72]. Among Brazilian people, up to $50 \%$ of elementary school children and $50-80 \%$ of women of child-bearing age have antibodies to T. gondii [23]. According to Shapiro et al. [71], the high prevalence of infection in this country is related to high environmental contamination by oocysts of the parasite. In addition, toxoplasmosis can determine severe clinical manifestations in adults and children from different regions of Brazil. According to Strang et al. [78], $48 \%$ of Brazilian children with congenital toxoplasmosis can develop retinochoroiditis, and 17\% brain calcifications, among other changes. Regarding ocular toxoplasmosis, there is a wide variety of clinical outcomes of the disease in Brazilian individuals, which may be related to the high genetic diversity of the parasite in the country [32, 41].

High anti-T. gondii antibody frequencies have been reported in domestic dogs and cats from Cuba, Mexico, Panama, Iran, Argentina, Portugal, Australia, Colombia, and Chile $[1,10,26,30,44,57,58,63,83,86]$. In Brazil, the frequency of $T$. gondii infection in Brazilian pet animal populations can vary from 9 to $70 \%$ in dogs and from 0 to $71 \%$ in cats $[5,9,35,47,50,68,81]$. Toxoplasma gondii seropositivity in pets can vary, not only between countries, but also between regions of the same country, and areas of the same city [20]. In general, domiciled animal populations or under the responsibility of owners have a lower frequency of anti- $T$. gondii antibodies compared to stray or shelter populations $[4,18,47,55,77$, 79]. Different risk factors for $T$. gondii infection have been identified in populations of domestic dogs and cats, including street access, contact with cats, and presence of rodents at home $[2,9,12,48,64,66,67,73]$. Among these factors, the type of diet of these animals stands out. Strital et al. [79] identified an association between $T$. gondii seropositivity and offal consumption in dogs treated at a university veterinary hospital.
According to Lucas et al. [45], diet and street access are important risk factors for cats. Coelho et al. [14] observed a positive association between diet and seropositivity in cats. In this study, all seropositive cats were fed homemade food, whereas cats fed exclusively with commercial food were not exposed to $T$. gondii [14]. In urban areas, where prey availability is low, the main source of infection by $T$. gondii for dogs and cats is the tissue cysts present in human food leftovers, available in garbage [49].

In 2013, according to the Brazilian Institute of Geography and Statistics (IBGE), the urban populations of domestic dogs and cats were 52.2 million and 22.1 million animals, respectively [39]. In the following six years, there was an increase in the number of households that have at least one pet in Brazil $[39,40]$. This increase in human habitations with pets can narrow the contact between humans and animals, favoring zoonosis transmission. However, the introduction and diversity of commercial cat food on the Brazilian pet market may reduce T. gondii exposure in pet cats, because the heating and high temperatures applied to industrialized cat food eliminate viable tissue cysts [49]. In this context, there is a lack on seroepidemiological data on the frequency of anti-T. gondii antibodies that include pet animals from different socioeconomic classes, raised under different forms of ownership. In addition, there are no studies that identify the geolocation of domiciled animals exposed to $T$. gondii in large urban centers. Moreover, recently the Municipal Health Department of Rio de Janeiro city, by means of Resolution 3784 of August 21, 2018, mandates the notification of confirmed cases of zoonoses in animals, including toxoplasmosis [69].

Due to the importance of the role of dogs and cats in the epidemiology of toxoplasmosis and the scarcity of studies on this subject in Rio de Janeiro, we studied anti-T. gondii antibodies in domiciled animals, associated with the use of questionnaires to owners of low socio-economic classes to identify risk factors for pets. The identification of risk factors for pets allows the adoption of preventive measures to minimize the exposure of these animals to the protozoan. Considering that the different ownership profiles of pet owners directly reflect the food management of their animals, the present study aimed to assess the frequency of $T$. gondii infection, the spatial distribution of these animals, and risk factors for this infection. The study examined domestic dogs and cats attended at the Municipal Institute of Veterinary Medicine Jorge Vaitsman, Rio de Janeiro, Brazil, to carry out a targeted information and prevention campaign on the risks of $T$. gondii transmission in pets but also in humans.

\section{Materials and methods}

\section{Ethical considerations}

This research was approved by the Ethics Committee on the Use of Animals, IOC/Fiocruz, under license L-019/2017; by the Human Research Ethics Committee, IOC/Fiocruz project CAAE: 67408817.9.0000.5248, with approval number 2,054,938; by the Scientific Committee of the Secretariat for Surveillance, Sanitary Inspection and Zoonosis Control of Rio de Janeiro city under licenses 001/17 and 004/20. 


\section{Animal population and study area}

The study included domestic dogs and cats seen in the routine of the medical clinic of the Municipal Institute of Veterinary Medicine Jorge Vaitsman (IJV) whose owners agreed to participate in the research by signing a free and informed consent form. The IJV is located in the São Cristóvão neighborhood in the northern zone of Rio de Janeiro city and is considered a reference center in epidemiological surveillance and in the control of zoonoses of public health importance [80]. The Institute offers various veterinary services to the population of Rio de Janeiro, such as clinical care for animals, especially dogs and cats, surgical procedures, diagnostic tests, and vaccination either free of charge or at affordable prices.

Between August 2017 and January 2020, serum samples from 400 dogs and 272 cats were collected from animals sent for biological sample collection for routine, preoperative, and/or diagnostic confirmation tests. Clinically healthy and ill animals, males and females of different ages, and different breeds were included by means of convenience sampling.

\section{Blood collection and serological test}

Blood samples were obtained through venipuncture of the cephalic, jugular, saphenolateral or femoral veins, with a maximum volume of $5 \mathrm{~mL}$ from healthy animals. In the case of young or clinically debilitated animals, a maximum volume of $3 \mathrm{~mL}$ or $6-7 \%$ of the animal's weight was collected [43]. The samples were placed in tubes without anticoagulant, kept under refrigeration at $4{ }^{\circ} \mathrm{C}$ and transported to the Toxoplasmosis and other Protozoan Diseases Laboratory (LabTOXO), Oswaldo Cruz Institute/Fiocruz.

In LabTOXO, blood samples were centrifuged at $1000 \times g$ for $10 \mathrm{~min}$ to obtain the serum. Serum samples were aliquoted in $1.5 \mathrm{~mL}$ microtubes, identified, and stored at $20{ }^{\circ} \mathrm{C}$ until the serological test was performed. The serum samples were analyzed for antibodies to $T$. gondii by the indirect fluorescent antibody test IFAT, as described by Camargo [11]. The T. gondii tachyzoites RH strain, maintained in Swiss Webster mice, was used as an antigen. Positive and negative controls of each species, stored in LabTOXO, were used for each reaction. For the detection of $\operatorname{IgG}$ anti- $T$. gondii antibodies, commercial anti-Cat IgG produced in goats, BioRad ${ }^{\circledR}$ and anti-Dog IgG produced in rabbit Sigma-Aldrich ${ }^{\circledR}$ conjugates diluted in Evans Blue solution were used. The samples were considered positive when total fluorescence of the tachyzoite surface was observed, with titers equal to or greater than 1:16 in dogs and 1:64 in cats $[5,61]$.

\section{Epidemiological questionnaire}

After the collection of blood samples, the animal owners were interviewed to answer a semi-structured epidemiological questionnaire composed of semi-open questions. This questionnaire included epidemiological variables related to general information about the animal's lifestyle and management. To identify possible risk factors for $T$. gondii infection in these animals, the following variables were selected: sex [52, 86], age $[5,65]$, breed $[6,56]$, street access $[9,67]$, contact with cats
$[12,66]$, presence of rodents [48], type of food (dry and wet commercial food, meat and embedded, homemade food, offal and other types of food, like fruits and vegetables) [14, 79] and water source for animals' consumption [8].

\section{Statistical analysis and georeferencing}

Serological and epidemiological data were analyzed using the Epi Info statistical program (version 7.2). Initially, an univariable exploratory analysis of the data was carried out for the selection of variables with $p \leq 0.2$ using the chi-square or Fischer exact tests. Subsequently, the significant variables passed to a multivariable analysis using the multiple logistic regression with significant level of 5\%. The existence of associated factors was estimated by multiple logistic regression and the strength of the association was estimated by odds ratio (OR) and their respective $95 \%$ confidence intervals. The animal's place of residence was recovered using semi-structured questionnaires. Maps of the distribution of sampled domestic dogs and cats from different areas of Rio de Janeiro city and neighborhood cities from the metropolitan region of Rio de Janeiro state were constructed using ArcGis 10.1.

\section{Results}

From the total number of animals evaluated, $34 \%$ of dogs (136/400) and $8.1 \%$ of cats $(22 / 272)$ had $\mathrm{IgG}$ antibodies against T. gondii. Among dogs, the most frequent antibody titers were $1: 16(53.7 \%)$, followed by $1: 64(33.8 \%), 1: 256(11 \%)$ and $1: 1024(1.5 \%)$. The most frequent titer among felines was 1:64 (59.1\%), followed by 1:256 (40.9\%).

Owners of $321(80.3 \%)$ dogs completely answered the questionnaire, while $36(9 \%)$ partially answered. In relation to cats, $218(80.1 \%)$ animals had their respective questionnaires completely answered by their owners, while 40 (14.7\%) feline questionnaires were incompletely answered. Data from 43 $(10.7 \%)$ dogs and $14(5.2 \%)$ cats were not recovered, as their owners did not answer the questionnaires.

Regarding the geographic location of the dogs' homes, 92.1\% (315/342) lived in Rio de Janeiro city. The other dogs came from other cities in the metropolitan region of Rio de Janeiro state, with $2.6 \%$ (9/342) from São João de Meriti, $1.4 \%$ (5/342) from Nova Iguaçu, $0.9 \%$ (3/342) from São Gonçalo, $0.9 \%$ (3/342) from Duque de Caxias, 0.6\% (2/342) from Belfort Roxo, $0.6 \%$ (2/342) from Mesquita, 0.3\% (1/342) from Magé, 0.3\% (1 /342) from Queimados, and $0.3 \%$ (1/342) from Itaboraí. Among the cats, 97.6\% (241/247) were from Rio de Janeiro city. The other cats came from São Gonçalo 0.8\% (2/247), Duque de Caxias $0.4 \%$ (1/247), Belford Roxo 0.4\% (1/247), Niterói 0.4\% (1/247), and Mesquita $0.4 \%(1 / 247)$. The addresses of $14.5 \%$ of dogs (58/400) and $9.2 \%$ of cats $(25 / 272)$ were not available because their owners did not inform them when filling out the epidemiological questionnaire.

As expected, the majority of $T$. gondii seropositive dogs, $89.6 \%$ (104/116) and all T. gondii seropositive cats, $100 \%$ (19/19) lived in Rio de Janeiro city, result directly observed by the concentration of geolocation points on the maps of the 

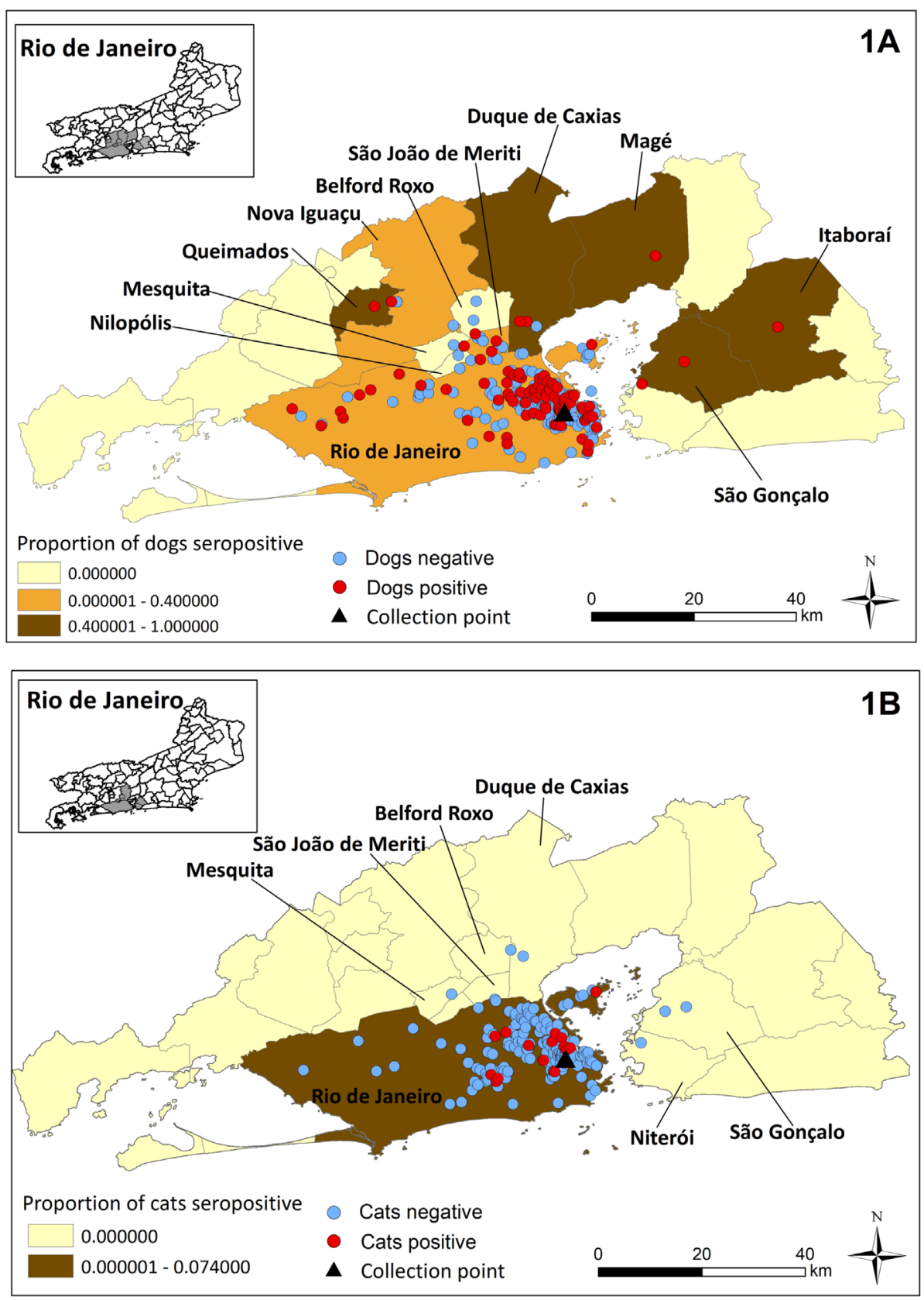

Figure 1. Spatial distribution of domiciled dogs (A) and cats (B) and proportion of $T$. gondii-seropositive animals by cities of the metropolitan region of Rio de Janeiro state.

metropolitan region of Rio de Janeiro state. The other 12 T. gondii-seropositive dogs lived in São Gonçalo (3 dogs), São João de Meriti (3 dogs), Duque de Caxias (2 dogs), Itaboraí (1 dog), Magé (1 dog), Nova Iguaçú (1 dog), and Queimados ( $1 \mathrm{dog})$ (Figs. 1A and 1B). Although there was a higher concentration of $T$. gondii-seropositive animals in the northern area of Rio de Janeiro city (Figs. 2A and 2B), proportionally, the region of the city that showed the highest frequency of seropositive dogs was the west zone, $43.2 \%(16 / 37)$ followed by north zone, $33.8 \%$ (76/225), south zone, $29.4 \%$ (5/17), and central zone, $19.4 \%$ (7/36). In relation to cats, the region that presented the highest proportional frequency of seropositive animals was also the west zone, $8.9 \%$ (4/45), followed by north zone, $8.2 \%$
(12/146), central zone, $7.7 \%$ (3/39), and south zone, $0 \%(0 / 11)$. There was no association between the $T$. gondii seropositivity and the pets' origin region in Rio de Janeiro city (Table 1).

The univariate data analysis revealed an association between the $T$. gondii seropositivity and the following variables: age, breed, and wet food, offal, and filtered water or other water sources for dogs (Table 2). In the final multiple regression model, breed and offal consumption were associated with $T$. gondii seropositivity $(p<0.05)$. Dogs without defined breed were twice as likely to be exposed to T. gondii (OR: $2.10-95 \%$ IC 1.27-3.46) compared to dogs with defined breed. Offal consumption increased twice (OR: 2.74-95\% IC 1.38-5.43) the chance of infection by $T$. gondii in the studied dogs (Table 3 ). 

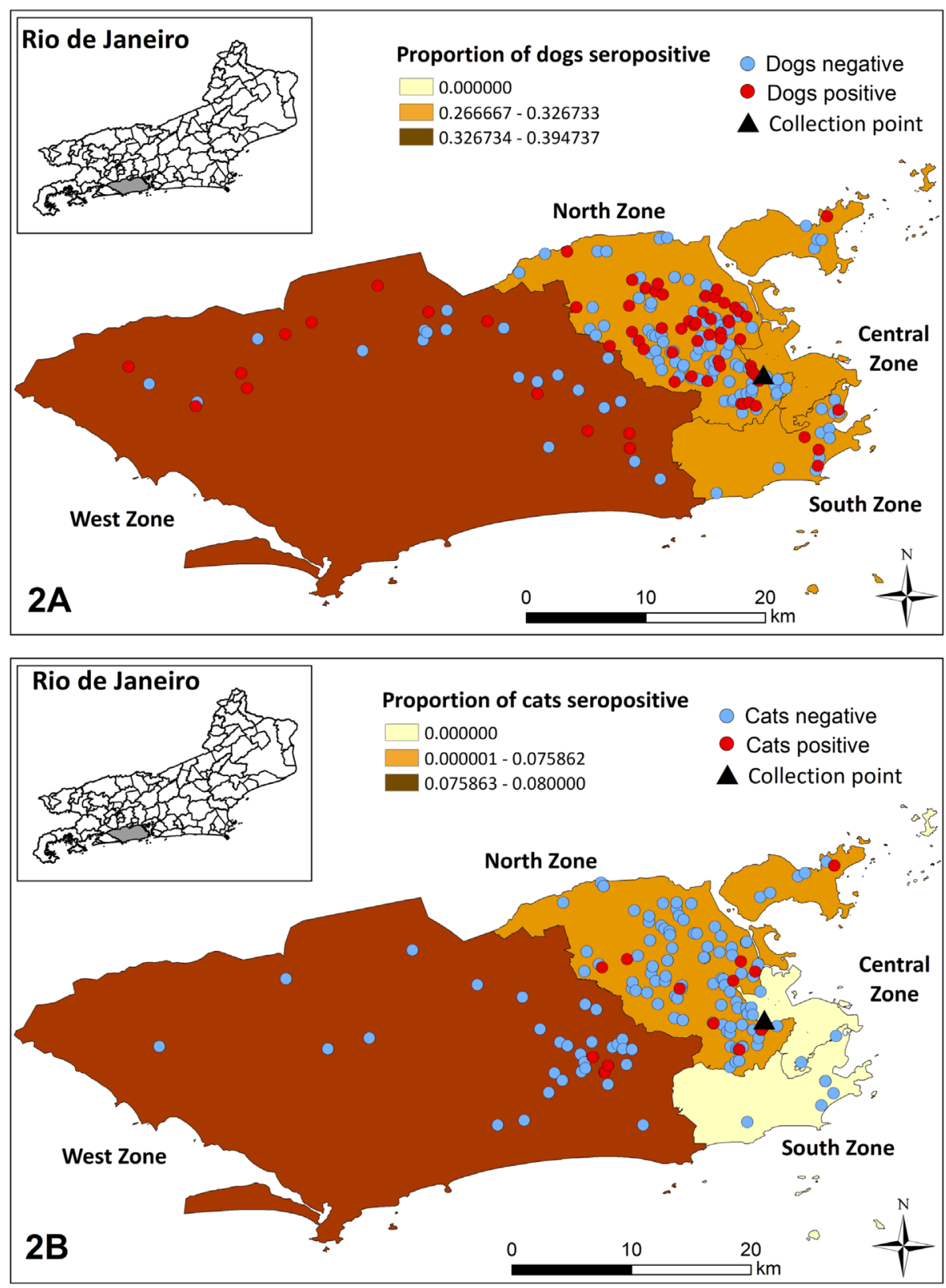

Figure 2. Spatial distribution of domiciled dogs (A) and cats (B) and proportion of T. gondii-seropositive animals by areas of Rio de Janeiro city.

Table 1. Frequencies of $T$. gondii-seropositive domestic dogs and cats by geographical region of Rio de Janeiro city treated at the Municipal Institute of Veterinary Medicine Jorge Vaitsman from August 2017 to January 2020.

\begin{tabular}{|c|c|c|c|c|c|c|}
\hline \multirow{2}{*}{$\begin{array}{l}\text { Geographical area in } \\
\text { Rio de Janeiro city }\end{array}$} & \multicolumn{3}{|c|}{ Dogs } & \multicolumn{3}{|c|}{ Cats } \\
\hline & $N$ & Positive (\%) & $p$-value & $N$ & Positive (\%) & $p$-value \\
\hline Central zone & 36 & 19.4 & 0.1787 & 39 & 7.7 & 0.7943 \\
\hline North zone & 225 & 33.8 & & 146 & 8.2 & \\
\hline South zone & 17 & 29.4 & & 11 & 0 & \\
\hline West zone & 37 & 43.2 & & 45 & 8.9 & \\
\hline Total & 315 & & & 241 & & \\
\hline
\end{tabular}

In cats, the selected variables in univariate analysis were sex, street access, meat and embedded, homemade food and offal consumption (Table 2). The final multiple regression model revealed an association between $T$. gondii seropositivity and sex, homemade food, and offal consumption $(p<0.05)$. Male cats were three times as likely to be exposed to $T$. gondii 
Table 2. Univariable analysis $(p \leq 0.20)$ of the associated factors with $T$. gondii infection in domestic dogs and cats treated at Municipal Institute of Veterinary Medicine Jorge Vaitsman from August 2017 to January 2020.

\begin{tabular}{|c|c|c|c|c|c|c|}
\hline \multirow[t]{2}{*}{ Variables } & \multicolumn{3}{|c|}{ Dogs } & \multicolumn{3}{|c|}{ Cats } \\
\hline & $N$ & Positive (\%) & $p$-value & $N$ & Positive (\%) & $p$-value \\
\hline \multicolumn{7}{|l|}{$\overline{\operatorname{Sex}}$} \\
\hline Females & 231 & 32.0 & $0.388^{\mathrm{a}}$ & 157 & 5.7 & $0.096^{\mathrm{a}, *}$ \\
\hline Males & 169 & 36.7 & & 115 & 11.3 & \\
\hline \multicolumn{7}{|l|}{ Age } \\
\hline$\leq 12$ months $^{\mathrm{c}}$ & 70 & 24.3 & & 94 & 5.3 & \\
\hline $13-36$ months & 63 & 46.0 & $0.008^{\mathrm{a}, *}$ & 60 & 5.0 & $1^{\mathrm{b}}$ \\
\hline$\geq 37$ months & 229 & 31.9 & $0.226^{\mathrm{b}}$ & 78 & 9.0 & $0.382^{\mathrm{b}}$ \\
\hline \multicolumn{7}{|l|}{ Breed } \\
\hline Defined & 191 & 25.1 & $0.001^{\mathrm{a}, *}$ & 24 & 8.3 & $1^{\mathrm{b}}$ \\
\hline Undefined & 197 & 42.1 & & 243 & 7.8 & \\
\hline \multicolumn{7}{|l|}{ Street access } \\
\hline Yes & 240 & 32.1 & $0.856^{\mathrm{a}}$ & 80 & 12.5 & $0.062^{\mathrm{a}, *}$ \\
\hline No & 134 & 33.6 & & 175 & 5.7 & \\
\hline \multicolumn{7}{|l|}{ Contact with cats } \\
\hline Yes & 93 & 38.7 & $0.283^{\mathrm{a}}$ & 240 & 8.3 & $1^{\mathrm{b}}$ \\
\hline No & 294 & 32.0 & & 3 & 0.0 & \\
\hline \multicolumn{7}{|l|}{ Presence of rodents } \\
\hline Yes & 109 & 32.1 & $0.838^{\mathrm{a}}$ & 61 & 11.5 & $0.224^{\mathrm{a}}$ \\
\hline No & 236 & 33.9 & & 181 & 6.6 & \\
\hline \multicolumn{7}{|l|}{ Type of food } \\
\hline Dry food & 367 & 33.2 & $0.308^{\mathrm{a}}$ & 255 & 7.4 & $1^{\mathrm{b}}$ \\
\hline Wet food & 77 & 42.9 & $0.087^{\mathrm{b}, *}$ & 114 & 8.8 & $0.460^{\mathrm{a}}$ \\
\hline Meat and embedded & 113 & 35.4 & $0.786^{\mathrm{a}}$ & 46 & 13.0 & $0.108^{\mathrm{a}, *}$ \\
\hline Homemade food & 179 & 36.9 & $0.306^{\mathrm{a}}$ & 36 & 22.2 & $0.0003^{\mathrm{a}, *}$ \\
\hline Offal & 43 & 53.5 & $0.007^{\mathrm{b}, *}$ & 17 & 23.5 & $0.028^{\mathrm{b}, *}$ \\
\hline Others & 44 & 31.8 & $0.884^{\mathrm{b}}$ & 4 & 0.0 & $1^{\mathrm{b}}$ \\
\hline \multicolumn{7}{|l|}{ Water source } \\
\hline Tap water & 214 & 36.4 & $0.236^{\mathrm{a}}$ & 149 & 8.7 & $0.391^{\mathrm{a}}$ \\
\hline Filtered water & 182 & 29.7 & $0.139^{\mathrm{a}, *}$ & 121 & 6.6 & $0.592^{\mathrm{a}}$ \\
\hline Other sources & 2 & 100 & $0.113^{\mathrm{b}, *}$ & 2 & 0.0 & $1^{\mathrm{b}}$ \\
\hline
\end{tabular}

${ }^{\text {a }} X$ test.

${ }^{\mathrm{b}}$ Fischer Exact test.

${ }^{\mathrm{c}}$ Reference category.

* Selected for multivariate analysis.

Table 3. Final models of logistic regression analysis from variables statistically $(p \leq 0.05)$ associated factors with $T$. gondii infection in domestic dogs and cats treated at Municipal Institute of Veterinary Medicine Jorge Vaitsman from August 2017 to January 2020.

\begin{tabular}{|c|c|c|c|c|c|c|c|}
\hline \multirow[t]{2}{*}{ Species } & \multirow[t]{2}{*}{ Variable } & \multicolumn{6}{|c|}{ Multiple logistic regression } \\
\hline & & Coefficient & $\begin{array}{l}\text { Standard } \\
\text { error }\end{array}$ & $P$-Wald & $\begin{array}{c}\text { Degrees of } \\
\text { freedom }\end{array}$ & $p$-value & Adjusted OR $[95 \% \mathrm{CI}]$ \\
\hline \multirow[t]{6}{*}{$\overline{\text { Dogs }}$} & Age & 0.1572 & 0.1552 & 1.0133 & 6 & 0.3109 & $1.1703[0.8634-1.5862]$ \\
\hline & Breed & 0.7444 & 0.2539 & 2.9314 & 6 & $0.0034 *$ & $2.1051[1.2798-3.4627]$ \\
\hline & Wet food & 0.4582 & 0.3009 & 1.5227 & 6 & 0.1278 & $1.5812[0.8767-2.8518]$ \\
\hline & Offal & 1.0094 & 0.3487 & 2.8951 & 6 & $0.0038^{*}$ & $2.7440[1.3855-5.4344]$ \\
\hline & Filtered water & -0.0909 & 0.2511 & -0.3620 & 6 & 0.7173 & $0.9131[0.5582-1.4936]$ \\
\hline & Other water sources & 11.9799 & 310.0049 & 0.0386 & 6 & 0.9692 & $159513.8940[0.0000>1.0 \mathrm{E} 12]$ \\
\hline \multirow[t]{5}{*}{ Cats } & Sex & 1.2259 & 0.5752 & 2.1311 & 5 & $0.0331 *$ & $3.4071[1.1035-10.5201]$ \\
\hline & Street access & 0.5349 & 0.5855 & 0.9135 & 5 & 0.3610 & $1.7072[0.5419-5.3786]$ \\
\hline & Meat and embedded & -1.2432 & 0.8846 & -1.4054 & 5 & 0.1599 & $0.2884[0.0509-1.6333]$ \\
\hline & Homemade food & 2.1390 & 0.6277 & 3.4077 & 5 & $0.0007 *$ & 8.4913 [2.4812-29.0591] \\
\hline & Offal & 2.0367 & 0.9285 & 2.1935 & 5 & $0.0283 *$ & $7.6652[1.2422-47.2995]$ \\
\hline
\end{tabular}

* Statistically associated. 
(OR: 3.40-95\% IC 1.10-10.52) compared to females. Homemade food and offal consumption increased the chance of $T$. gondii exposure in the evaluated cats by eight (OR: 8.49-95\% IC 2.48-29.05) and seven (OR: 7.66-95\% IC 1.24-47.29) times, respectively (Table 3 ).

\section{Discussion}

In this study, the frequency of seropositive dogs (34\%) for T. gondii was higher than cats $(8.1 \%)$. In other studies also carried out in Rio de Janeiro state, which included domiciled dogs and cats, seropositivity for anti-T. gondii were found to be higher for dogs $(46.1 \%)$ and lower for cats (5.6-6.6\%) $[3,4,16]$. Although these studies also included domiciled animals, Bastos et al. [4] and Cunha et al. [16] used indirect hemagglutination test (HAI) and enzyme linked immunosorbent assay (ELISA) as a serological test for the detection of antibodies anti- $T$. gondii in pets, respectively. Barros et al. [3], evaluated the presence of antibodies against $T$. gondii, also by IFAT, but only in domiciled cats with sporotrichosis treated at Laboratory of Clinical Research in Dermatozoonosis in Domestic Animals National Institute of Infectious Diseases (INI) / Fiocruz. In the present study, we chose to use IFAT for detection of antibodies against $T$. gondii in pet animals because this serological test is recommended for defining the true serological status of dogs and cats [46]. It is important to note that comparisons between these studies should be interpreted with caution, considering the use of different serological techniques, established cut-off points, and conditions for handling the animals. However, the serological results of the present study confirm those previously carried found in the same region, identifying similar seropositivity to those already reported in pet animals in Rio de Janeiro. In addition, unlike the previous studies, the present study included dog and cat populations analyzed simultaneously, in a socio-economically heterogeneous sample panel, as the sample collection was carried out in a Municipal Institution of notorious public health recognition.

The greater seropositivity evidenced in dogs compared to cats for $T$. gondii in Rio de Janeiro may be related to several factors, including the feeding behavior of the two animal species. This profile was also observed by Meireles et al. [49] in stray dogs and cats in São Paulo, Brazil. While dogs are less selective in their search for food, cats are strictly carnivorous animals; in other words, their diet consists exclusively of meat-based foods. Moreover, cats drink less water and eat smaller amount of food than dogs, which may reduce their exposure to $T$. gondii [49]. Therefore, dogs may be more likely to ingest one of the $T$. gondii evolutionary forms, including tissue cysts in raw or undercooked meat or oocysts in raw foods contaminated with feline feces, such as fruits and vegetables. The lower seropositivity in the cats tested than in the other studies may be related to the high proportion of cats fed commercial dry food in the population analyzed. Another factor that may be related to the higher frequency of infection in dogs than in cats is the habit of their owners walking in the streets with their dogs, a common practice in tropical regions, such as Rio de Janeiro state. While most dogs are taken out for a walk on the street and defecate, most cats are kept confined in the home environment. This restriction of the circulation environment may minimize the exposure of felines to the outdoor environment, possibly contaminated with $T$. gondii oocysts and inhabited by potential chronically infected intermediate hosts. It is important to highlight that the stray cat populations, resident in different areas of Rio de Janeiro city, are exposed to $T$. gondii, suggesting that these animals may be contributing to the contamination of the environment by oocysts in the study area [7, 51, 61].

The large number of seronegative cats observed in the cat population studied is of great importance, since if exposed to $T$. gondii, these animals will be able to spread large amounts of oocysts in the home or peridomiciliar environment, increasing the risk of infection by their owners and other animals. Therefore, preventive measures should be directed mainly to the seronegative cat population [24]. The occurrence of seropositive dogs can be considered a parameter of environmental contamination by the protozoan [6, 84]. According Boa Sorte et al. [6] and Ullmann et al. [84], the high prevalence of infected dogs in Brazil is due to the exposure of the dogs to waste and environmental contamination with $T$. gondii oocysts, showing the role of the dog as a sentinel animal for toxoplasmosis. Gao et al. [33] and Meireles et al. [49] indicates that canine toxoplasmosis might be an important epidemiological indicator of the risk of toxoplasmosis to humans. In addition to their role as a sentinel species, domestic dogs can mechanically carry $T$. gondii oocysts in their gastrointestinal tract through coprophagy after ingesting cat feces containing oocysts [31, 42]. Thus, the detection of $T$. gondii seropositive domiciled dogs in this study may indicate contamination of the environment shared with their owners.

In the present study, most seropositive dogs had low antibody titers detected by IFAT $(53.7 \%$ at $1: 16)$. This profile was also reported by Strital et al. [79] in dogs attended at the Veterinary School Hospital of the University of Mato Grosso (1:16-46\%), by Brasil [9] in domiciled dogs attended at 34 veterinary clinics in Paraíba (1:16-35.1\%), both in Brazil and by Hosseininejad et al. [38], in domiciled and stray dogs in Iran (1:16-42.7\%). In relation to the seropositive cats detected in this study, the titration most frequently observed in IFAT was 1:64 (59.1\%). This titration was also the most frequent in domiciled cats in Paraná and Acre, Brazil, and in domiciled cats in Iran, when the same technique was used [15, 36, 76]. In the Czech Republic, Sedlak and Bartova [70] reported high IgG titers in samples of domiciled dogs and cats submitted to IFAT of 1:10,240 and 1:81,920, respectively.

Despite the phylogenetic proximity of $T$. gondii and Neospora caninum, coccidia that have dogs and other canids as definitive hosts, the frequency of cross-reaction between antibodies against these protozoa is low in serum samples from dogs [37]. Thus, the establishment of the 1:16 titration as a cut-off point for serology in dogs evaluated in this study may have favored an increase in the sensitivity of the technique, that is, the detection of animals truly exposed to $T$. gondii. In contrast, the antigenic similarity between $T$. gondii and Hammondia hammondi, another Sarcocystidae coccidian that also has domestic cats as the definitive host, allows the occurrence of a cross-reaction between antibodies against these 
agents [34]. For this reason, the choice of 1:64 titration in cats included in the present study aimed to reduce the possibility of cross-reaction, in view of the more precise discrimination between felines truly exposed to $T$. gondii. It is worth mentioning that such differentiation is of great importance in public health, since $H$. hammondi has no potential for zoonotic transmission, such as $T$. gondii.

Although the sample size was not representative, the spatialization of sampled pets, especially dogs, showed that $T$. gondii can be widely disseminated, as was evidenced in dogs from 8 of the 19 cities of the metropolitan region of Rio de Janeiro state. In relation to the areas of Rio de Janeiro city, the plotting of the points referring to dogs indicated the circulation of the protozoan in all areas of the state capital, especially west zone. It is important to highlight that this region of Rio de Janeiro city concentrates neighborhoods with markedly different socio-economic profiles, including those with low social indicators, a scenario that may have favored the formation of seropositive animal clusters in this region. In this context, precarious animal handling with the supply of food leftovers, access to garbage, low sanitary conditions, the presence of synanthropic animals, and little concern by owners with animal health is included. For cats, spatial analysis indicated that oocysts of the parasite possibly contaminated the environment in all areas of Rio de Janeiro city, once there was no difference between frequencies of seropositive cats from different regions. The information generated from the spatial distribution of the animals, highlights the need to carry out actions and awareness campaigns for owners in all parts of the city, to mediate information about the control of $T$. gondii infection in these animals.

In this study, male cats were more exposed to $T$. gondii than females. However, Neves et al. [58] and Pereira et al. [61] found no association between sex and the presence of antiT. gondii antibodies in other feline populations. According to Miró et al. [52] and Smith et al. [74], due to the explorative behavior of males, they end up being more prone to T. gondii infection than females. This exploratory behavior, possibly related to a higher energy requirement, may have contributed to the significantly higher frequency of seropositive male cats evaluated in this study. Undefined breed dogs had a higher frequency of anti- $T$. gondii antibodies than pure breed dogs. This profile was also evident in domiciled dogs in Tocantins and Mato Grosso, Brazil [6, 62]. This fact may be related to the difference in the types of care and sanitary management performed by their owners. In this sense, it is possible that owners of mixed breed dogs were investing little or no resources in the management of animals. Considering that dogs of different breeds are susceptible to $T$. gondii infection, the higher frequency of undefined breed dogs seropositive for T. gondii in this study may also be related to the eating habits of these animals.

This study confirmed that the supply of offal is an important risk factor for $T$. gondii infection in evaluated pets. Also, the consumption of homemade food was associated with greater exposure to the protozoan only in the feline population. The consumption of raw meat, offal and leftover homemade food was also associated with seropositivity for $T$. gondii in other populations of domiciled dogs and cats in Brazil and in other countries $[10,13,54,75,79]$. This result indicates that the exposure of domiciled dogs and cats to $T$. gondii occurs in the home environment through the supply of these foods by the owners. This behavior by some owners may favor the ingestion of viable tissue cysts present in the raw meat and offal offered to the animals. In addition, improper washing of raw food and cooking meat at low temperatures can be ineffective for inactivating infectious forms of the protozoan. The supply of these types of food added to the lack of knowledge about toxoplasmosis, as well as their transmission pathways and preventive measures by owners may have contributed to the exposure of dogs and cats to the parasite.

Given the above, the adoption of appropriate management practices, such the exclusive supply of industrialized food and the restriction of access of animals to places possibly contaminated by oocysts and/or cohabited by potential intermediate hosts can minimize the exposure of pet animals to T. gondii. This study confirms the importance of informing dog and cat owners not to feed raw food, especially offal, to their pets. The adoption of these prophylactic measures to control T. gondii infection in pet populations should be increasingly encouraged in public spaces, such as the Jorge Vaitsman Institute, where veterinarians work in clinical care, as well as in sensitizing owners to disseminate prophylactic information which indirectly contributes positively to public health.

\section{Conflict of interest}

The authors declare that they have no conflict of interest.

Acknowledgements. We thank Cristiane Ferreira Vieira and all members of Laboratório Municipal de Saúde Pública do Instituto Municipal de Medicina Veterinária Jorge Vaitsman for technical support during the collection of biological samples. We also thank Ana Beatriz Monteiro Fonseca for her support in the statistical analysis. Thanks are also extended to Coordenação de Aperfeiçoamento de Pessoal de Nível Superior (CAPES) and Fundação Carlos Chagas Filho de Amparo à Pesquisa do Estado do Rio de Janeiro (FAPERJ) for financial support.

\section{References}

1. Alvarado-Esquivel C, Romero-Salas D, Cruz-Romero A, García-Vázquez Z, Peniche-Cardeña A, Ibarra-Priego N, Ahuja-Aguirre C, Pérez-de-León AA, Dubey JP. 2014. High prevalence of Toxoplasma gondii antibodies in dogs in Veracruz, Mexico. BMC Veterinary Research, 10, 191.

2. Ayinmode AB, Adediran AO, Schares G. 2016. Seroprevalence of Toxoplasma gondii and Neospora caninum in urban and rural dogs from southwestern Nigeria. African Journal of Infectious Diseases, 10(1), 25-28.

3. Barros RS, Menezes RC, Pereira SA, Figueiredo FB, Oliveira RVC, Nicolau JL, Neves LB, Millar PR, Kitada AAB, Amendoeira MRR. 2015. Feline sporotrichosis: coinfection with Toxoplasma gondii, Feline Immunodeficiency Virus and Feline Leukemia Virus in cats from an endemic area in Brazil. Acta Scientiae Veterinariae, 43, 1-6.

4. Bastos BF, Brener B, Gershony L, Willi L, Labarthe N, Pereira C, Mendes-de-Almeida F. 2014. Seroprevalence of Toxoplasma gondii (Nicolle \& Manceaux, 1909) and retroviral 
status of client-owned pet cats (Felis catus, Linnaeus, 1758) in Rio de Janeiro, Brazil. Revista do Instituto de Medicina Tropical, São Paulo, 56(3), 201-203.

5. Benitez AN, Martins FDC, Mareze M, Santos NJR, Ferreira FP, Martins CM, Garcia JL, Mitsuka-Breganó R, Freire RL, Biondo AW, Navarro IT. 2017. Spatial and simultaneous representative seroprevalence of anti- Toxoplasma gondii antibodies in owners and their domiciled dogs in a major city of southern Brazil. PLoS One, 12(7), e0180906.

6. Boa Sorte EC, Almeida ABPF, Cruz FACS, Gasparetto ND, Godoy I, Dutra V, Amendoeira MRR, Sousa VRF. 2015. Serological and molecular detection of Toxoplasma gondii in dogs of urban and rural areas of Cuiabá, Mato Grosso. Semina: Ciências Agrárias, Londrina, 36(6), 3705-3712.

7. Bolais PF, Vignoles P, Pereira PF, Keim R, Aroussi A, Ismail K, Dardé ML, Amendoeira MR, Mercier A. 2017. Toxoplasma gondii survey in cats from two environments of the city of Rio de Janeiro, Brazil by Modified Agglutination Test on sera and filter-paper. Parasites \& Vectors, 10(1), 88.

8. Braga MSCO, André MR, Jusi MMG, Freschi CR, Teixeira MCA, Machado RZ. 2012. Occurrence of anti-Toxoplasma gondii and anti-Neospora caninum antibodies in cats with outdoor access in São Luís, Maranhão, Brazil. Revista Brasileira de Parasitologia Veterinária, 21(2), 107-111.

9. Brasil AWL, Parentoni RN, Silva JG, Santos CSAB, Mota RA, Azevedo SS. 2018. Risk factors and anti-Toxoplasma gondii and Neospora caninum antibody occurence in dogs in João Pessoa, Paraíba state, Northeastern Brazil. Brazilian Journal of Veterinary Parasitology, Jaboticabal, 27(2), 242-247.

10. Brennan A, Hawley J, Dhand N, Boland L, Beatty JA, Lappin MR, Barrs VR. 2020. Seroprevalence and risk ractors for Toxoplasma gondii infection in owned domestic cats in Australia. Vector Borne and Zoonotic Diseases, 20(4), 275-280.

11. Camargo M. 1964. Improved technique of indirect immunofluorescence for serological diagnosis of toxoplasmosis. Revista do Instituto de Medicina Tropical, São Paulo, 6(3), 117-118.

12. Castillo-Morales VJ, Acosta Viana KY, Guzmán-Marín Edel S, Jiménez-Coello M, Segura-Correa JC, Aguilar-Caballero AJ, Ortega-Pacheco A. 2012. Prevalence and risk factors of Toxoplasma gondii Infection in domestic cats from the tropics of Mexico using serological and molecular tests. Interdisciplinary Perspectives Infectious Diseases, 2012, 529108.

13. Cerro L, Rubio A, Pinedo R, Mendes-de-Almeida F, Brener B, Labarthe N. 2014. Seroprevalence of Toxoplasma gondii in cats (Felis catus, Linnaeus 1758) living in Lima, Peru. Brazilian Journal of Veterinary Parasitology, Jaboticabal, 23(1), 90-93.

14. Coelho WM, do Amarante AF, Apolinário Jde C, Coelho NM, de Lima VM, Perri SH, Bresciani KD. 2011. Seroepidemiology of Toxoplasma gondii, Neospora caninum, and Leishmania spp. infections and risk factors for cats from Brazil. Parasitology Research, 109(4), 1009-1013.

15. Cruz MA, Ullmann LS, Montaño PY, Hoffmann JL, Langoni H, Biondo AW. 2011. Seroprevalence of Toxoplasma gondii infection in cats from Curitiba, Paraná, Brazil. Revista Brasileira de Parasitologia Veterinária, Jaboticabal, 20(3), 256-258.

16. da Cunha NC, Cordeiro MD, Bravo SAC, Matos PCM, Almosny NRP, Fonseca AH. 2016. Soroepidemiologia de Toxoplasma gondii em cães no estado do Rio de Janeiro. Revista Brasileira de Medicina Veterinária, 38(Suppl. 3), 109-112.

17. Dabritz HA, Conrad PA. 2010. Cats and Toxoplasma: implications for public health. Zoonoses and Public Health, 57, 34-52.

18. de Paula Dreer MK, Gonçalves DD, Caetano ICS, Gerônimo E, Menegas PH, Bergo D, Lopes-Mori FMR, Benitez A, de Freitas JC, Evers F, Navarro IT, Martins LA. 2013. Toxoplasmosis, leptospirosis and brucellosis in stray dogs housed at the shelter in Umuarama municipality, Paraná, Brazil. Journal of Venomous Animals and Toxins including Tropical Diseases, 19(23), 1-5.

19. Djurkovic-Djakovic O, Dupouy-Camet J, Van der Giessen J, Dubey JP. 2019. Toxoplasmosis: overview from a One Health perspective. Food and Waterborne Parasitology, 15, e00054.

20. Dubey JP, Cerqueira-Cézar CK, Murata FHA, Kwok OCH, Yang Y, Su C. 2020. All about toxoplasmosis in cats: the last decade. Veterinary Parasitology, 283, 1-30.

21. Dubey JP, Cortés-Vecino JA, Vargas-Duarte JJ, Sundar N, Velmurugan GV, Bandini LM, Polo LJ, Zambrano L, Mora LE, Kwok OCH, Smith T, Su C. 2007. Prevalence of Toxoplasma gondii in dogs from Colombia, South America and genetic characterization of $T$. gondii isolates. Veterinary Parasitology, $145,45-50$.

22. Dubey JP, Kotula AW, Sharar A, Andrews CD, Lindsay DS. 1990. Effect of high temperature on infectivity of Toxoplasma gondii tissue cysts in pork. Journal of Parasitology, 76(2), 201-2044.

23. Dubey JP, Lago EG, Gennari SM, Su C, Jones JL. 2012. Toxoplasmosis in humans and animals in Brazil: high prevalence, high burden of disease, and epidemiology. Parasitology, 139(11), 1375-1424.

24. Dubey JP, Lindsay DS, Lappin MR. 2009. Toxoplasmosis and other intestinal coccidial infections in cats and dogs. Veterinary Clinics of North America: Small Animal Practice, 39, 1009-1034.

25. Dubey JP, Murata FHA, Cerqueira-Cézar CK, Kwok OCH, Yang Y, Su C. 2020. Toxoplasma gondii infections in dogs: 2009-2020. Veterinary Parasitology, 287, e00054.

26. Dubey JP, Su C, Cortés JA, Sundar N, Gomez-Marin JE, Polo LJ, Zambrano L, Mora LE, Lora F, Jimenez J, Kwok OC, Shen SK, Zhang X, Nieto A, Thulliez P. 2006. Prevalence of Toxoplasma gondii in cats from Colombia, South America and genetic characterization of $T$. gondii isolates. Veterinary Parasitology, 141, 42-47.

27. Dubey JP. 1991. Toxoplasmosis - an overview. Southeast Asian Journal of Tropical Medicine and Public Health, 22(Suppl.), 88-92.

28. Dubey JP. 1998. Toxoplasma gondii oocysts survival under defined temperatures. Journal of Parasitology, 84(4), 862-865.

29. Elmore SA, Jones JL, Conrad PA, Patton S, Lindsay DS, Dubey JP. 2010. Toxoplasma gondii: epidemiology, feline clinical aspects, and prevention. Trends in Parasitology, 26(4), 190-196.

30. Enriquez GF, Macchiaverna NP, Argibay HD, López Arias L, Farber M, Gürtler RE, Cardinal MV, Garbossa G. 2019. Polyparasitism and zoonotic parasites in dogs from a rural area of the Argentine Chaco. Veterinary Parasitology: Regional Studies and Reports, 16, 100287.

31. Frenkel JK, Parker BB. 1996. An apparent role of dogs in the transmission of Toxoplasma gondii: the probable importance of xenosmophilia. Annals of the New York Academy of Sciences, 791(1), 402-407.

32. Furtado JM, Lansingh VC, Carter MJ, Milanese MF, Peña BN, Ghersi HA, Bote PL, Nano ME, Silva JC. 2012. Causes of blindness and visual impairment in Latin America. Survey of Ophthalmology, 57(2), 149-177.

33. Gao YM, Ding H, Lamberton PHL, Lu DB. 2016. Prevalence of Toxoplasma gondii in pet dogs in mainland China: a metaanalysis. Veterinary Parasitology, 229, 126-130.

34. Gondim L, Mineo JR, Schares G. 2017. Importance of serological cross-reactivity among Toxoplasma gondii, Hammondia spp., Neospora spp., Sarcocystis spp. and Besnoitia besnoiti. Parasitology, 144(7), 851-868. 
35. Guimarães AM, Rocha CMBM, Oliveira TMFS, Rosado IR, Morais LG, Santos RRD. 2009. Fatores associados à soropositividade para Babesia, Toxoplasma, Neospora e Leishmania em cães atendidos em nove clínicas veterinárias do município de Lavras, MG. Revista Brasileira de Parasitologia Veterinária, 18(Suppl. 1), 40-53.

36. Haddadzadeh HR, Khazraiinia P, Aslani M, Rezaeian M, Jamshidi S, Taheri M, Bahonar A. 2006. Seroprevalence of Toxoplasma gondii infection in stray and household cats in Tehran. Veterinary Parasitology, 138, 211-216.

37. Higa AC, Machado RZ, Tinucci-Costa M, Domingues LM, Malheiros EB. 2000. Evaluation of cross-reactivity of Toxoplasma gondii and Neospora caninum antigens in dogs sera. Revista Brasileira de Parasitologia Veterinária, Jaboticabal, 9 (2), 91-95.

38. Hosseininejad M, Malmasi A, Hosseini F, Selk-Ghaffari M, Khorrami N, Mohebali M, Shojaee S, Mirani A, Azizzadeh M, Mirshokraei P, Aliari A. 2011. Seroprevalence of Toxoplasma gondii infection in dogs in Tehran, Iran. Iranian Journal of Parasitology, 6(1), 81-85.

39. IBGE. 2013. Pesquisa Nacional de Saúde. Rio de Janeiro: Fundação Instituto Brasileiro de Geografia e Estatística. https:// biblioteca.ibge.gov.br/pt/biblioteca-catalogo?view=detalhes\& id $=294074$.

40. IBGE. 2019. Pesquisa Nacional de Saúde. Rio de Janeiro: Fundação Instituto Brasileiro de Geografia e Estatística. https:// biblioteca.ibge.gov.br/index.php/biblioteca-catalogo?view=detalhes \&id=2101748.

41. Khan A, Jordan C, Muccioli C, Vallochi AL, Rizzo LV, Belfort R Jr, Vitor RW, Silveira C, Sibley LD. 2006. Genetic divergence of Toxoplasma gondii strains associated with ocular toxoplasmosis, Brazil. Emerging Infectious Diseases, 12(6), 942-949.

42. Lindsay DS, Dubey JP, Butler JM, Blagburn BL. 1997. Mechanical transmission of Toxoplasma gondii oocysts by dogs. Veterinary Parasitology, 73, 27-33.

43. Lopes ST, Biondo AW, dos Santos AP. 2007. Manual de Patologia Clínica Veterinária, $3^{\underline{a}}$ edição. Santa Maria: UFSM Universidade Federal de Santa Maria, Departamento de Clínica de Pequenos Animais.

44. López C, Daprato B, Zampolini S, Mazzeo C, Cardillo N, Sommerfelt I. 2011. Risk factors and prevalence of $\mathrm{IgG}$ antibodies to Toxoplasma gondii in domestic cats, La Matanza Buenos Aires, Argentina. Revista Ibero-latinoamericana de Parasitologia, 70(1), 29-34.

45. Lucas SRR, Hagiwara MK, Loureiro VDS, Ikesaki JYH, Birgel EH. 1999. Toxoplasma gondii infection in Brazilian domestic outpatient cats. Revista do Instituto de Medicina Tropical de São Paulo, 41(4), 221-224.

46. Macrì G, Sala M, Linder AM, Pettirossi N, Scarpulla M. 2009. Comparison of indirect fluorescent antibody test and modified agglutination test for detecting Toxoplasma gondii immunoglobulin $\mathrm{G}$ antibodies in dog and cat. Parasitology Research, 105(1), 35-40.

47. Magalhães FJR, Ribeiro-Andrade M, Souza FM, Lima Filho CDF, Biondo AW, Vidotto O, Navarro IT, Mota RA. 2017. Seroprevalence and spatial distribution of Toxoplasma gondii infection in cats, dogs, pigs and equines of the Fernando de Noronha Island, Brazil. Parasitology International, 66, 43-46.

48. Mascolli R, Soto FRM, Bernardi F, Ito FH, Pinheiro SR, Guilloux AGA, Azevedo SS, Silva PV, Gennari SM, Fernandes ARF, Pena HFJ, Vasconcellos SA. 2015. Seroprevalence and risk factors for toxoplasmosis and neosporosis in the dog population of Ibiúna, São Paulo, Brazil. Semina: Ciências Agrárias, 36(6), 3777-3785.
49. Meireles LR, Galisteo AJ Jr, Pompeu E, Andrade HF Jr. 2004. Toxoplasma gondii spreading in an urban area evaluated by seroprevalence in free-living cats and dogs. Tropical Medicine and International Health, 9(8), 876-881.

50. Melo RPB, Almeida JC, Lima DCV, Pedrosa CM, Magalhães FJR, Alcântra AM, Barros LD, Vieira RFC, Garcia JL, Mota RA. 2016. Atypical Toxoplasma gondii genotype in feral cats from the Fernando de Noronha Island, northeastern Brazil. Veterinary Parasitology, 224, 92-95.

51. Mendes-de-Almeida F, Labarthe N, Guerrero J, Faria MC, Branco AS, Pereira CD, Barreira JD, Pereira MJ. 2007. Followup of the health conditions of an urban colony of free-roaming cats (Felis catus Linnaeus, 1758) in the city of Rio de Janeiro, Brazil. Veterinary Parasitology, 147, 9-15.

52. Miró G, Montoya A, Jiménez S, Frisuelos C, Mateo M, Fuentes I. 2004. Prevalence of antibodies to Toxoplasma gondii and intestinal parasites in stray, farm and household cats in Spain. Veterinary Parasitology, 126(3), 249-255.

53. Montazeri M, Galeh TM, Moosazadeh M, Sarvi S, Dodangeh S, Javidnia J, Sharif M, Daryani A. 2020. The global serological prevalence of Toxoplasma gondii in felids during the last five decades (1967-2017): a systematic review and meta-analysis. Parasites \& Vectors, 13, 82.

54. Moura AB, Souza AP, Sartor AA, Bellato V, Teixeira EB, Pisetta GM, Heusser Junior A. 2009. Ocorrência de anticorpos e fatores de risco para infecção por Toxoplasma gondii em cães, nas cidades de Lages e Balneário Camboriú, Santa Catarina, Brasil. Revista Brasileira de Parasitologia Veterinária, Jaboticabal, 18(3), 52-56.

55. Munhoz AD, Hage SB, Cruz RDS, Calazans APF, Silva FL, Albuquerque GR, Lacerda LC. 2017. Toxoplasmosis in cats in northeastern Brazil: frequency, associated factors and coinfection with Neospora caninum, feline immunodeficiency virus and feline leukemia virus. Veterinary Parasitology: Regional Studies and Reports, 8, 35-38.

56. Must K, Hytönen MK, Orro T, Lohi H, Jokelainen P. 2017. Toxoplasma gondii seroprevalence varies by cat breed. PLoS One, 12(9), e0184659.

57. Navarrete MG, Cordeiro MD, Batista Y, Alonso JC, Márquez M, Roque E, Fonseca A. 2017. Serological detection of Toxoplasma gondii in domestic dogs in the western region of Cuba. Veterinary Parasitology: Regional Studies and Reports, 9, 9-12.

58. Neves M, Lopes AP, Martins $C$, Fino R, Paixão $C$, Damil L, Lima C, Alho AM, Schallig HDFH, Dubey JP, Cardoso L. 2020. Survey of Dirofilaria immitis antigen and antibodies to Leishmania infantum and Toxoplasma gondii in cats from Madeira Island, Portugal. Parasites \& Vectors, 13(117), 1-7.

59. Pena HF, Soares RM, Amaku M, Dubey JP, Gennari SM. 2006. Toxoplasma gondii infection in cats from São Paulo state, Brazil: seroprevalence, oocyst shedding, isolation in mice, and biologic and molecular characterization. Research in Veterinary Science, 81(1), 58-67.

60. Pena HFJ, Evangelista CM, Casagrande RA, Biezus G, Wisser CS, Ferian PE, Moura AB, Rolim VM, Driemeier D, Oliveira S, Alves BF, Gennari SM, Traverso SD. 2017. Fatal toxoplasmosis in an immunosuppressed domestic cat from Brazil caused by Toxoplasma gondii clonal type I. Revista Brasileira de Parasitologia Veterinária, 26(2), 177-184.

61. Pereira PF, Barbosa AS, Santos ALC, Bolais PF, Dardé ML, Amendoeira MRR. 2018. Toxoplasma gondii: infection among shelter and stray cats in Rio de Janeiro, Brazil. Brazilian Journal of Veterinary Parasitology, Jaboticabal, 27(3), 401-408. 
62. Raimundo JM, Guimarães A, Moraes LMB, Santos LA, Nepomuceno LL, Barbosa SM, Pires MS, Santos HA, Massard CL, Machado RZ, Baldani CD. 2015. Toxoplasma gondii and Neospora caninum in dogs from the state of Tocantins: serology and associated factors. Brazilian Journal of Veterinary Parasitology, Jaboticabal, 24(4), 475-481.

63. Rengifo-Herrera C, Pile E, García A, Pérez A, Pérez D, Nguyen FK, Guardia V, Mcleod R, Caballero Z. 2017. Seroprevalence of Toxoplasma gondii in domestic pets from metropolitan regions of Panama. Parasite, 24, 9.

64. Rocchigiani G, Nardoni S, Amato E, Tempori C, Mancianti F. 2016. Occurrence of anti Toxoplasma antibodies in owned dogs from Italy: a retrospective study. Slovenian Veterinary Research, 53(2), 63-67.

65. Rocha KS, Lima MS, Monteiro TRM, Honorio BET, Pinho APVB, Paz GS, Scofield A, Cavalcante GG, Magalhães-Matos PC, Sampaio Junior FD, Abel I, Langoni H, Moraes CCG. 2020. Serological prevalence of Toxoplasma gondii infection in cats (Belém, Pará, Brazil). Revista Brasileira de Parasitologia Veterinária, 29(2), e022719.

66. Rodrigues JY, Almeida AD, Boa Sorte ED, Gasparetto ND, Cruz FA, Sousa VR. 2016. Seroprevalence of Toxoplasma gondii in dogs of riverside communities of Mato Grosso Pantanal, Brazil. Revista Brasileira de Parasitologia Veterinária, 25(4), 531-535.

67. Rosa LD, Moura AB, Trevisani N, Medeiros AP, Sartor AA, Souza AP, Bellato V. 2010. Toxoplasma gondii antibodies on domiciled cats from Lages municipality, Santa Catarina State, Brazil. Revista Brasileira de Parasitologia Veterinária, 19(4), 268-269.

68. Ruffolo BB, Toledo RS, Martins FDC, Bugni FM, Costa L, Marana ERM, Navarro IT, Garcia JL, Su C, Freire RL. 2016. Isolation and genotyping of Toxoplasma gondii in seronegative urban rats and presence of antibodies in communicating dogs in Brazil. Revista do Instituto de Medicina Tropical, São Paulo, $58(28), 1-6$.

69. Secretaria Municipal de Saúde do Município do Rio de Janeiro. 2018. Resolução n⿳03784 de 21 de agosto de 2018, in Diário Oficial do Município do Rio de Janeiro de 22 de agosto de 2018. p. 16. https://www.jusbrasil.com.br/diarios/204997623/dom-rjnormal-22-08-2018-pg-16.

70. Sedlak K, Bartova E. 2006. The prevalence of Toxoplasma gondii IgM and IgG antibodies in dogs and cats from the Czech Republic. Veterinární Medicína, 51(12), 555-558.

71. Shapiro K, Bahia-Oliveira L, Dixon B, Dumètre A, de Wit LA, VanWormer E, Villena I. 2019. Environmental transmission of Toxoplasma gondii: Oocysts in water, soil and food. Food and Waterborne Parasitology, 12, 1-18.

72. Silva JCR, Ferreira F, Dias RA, Ajzenberg D, Marvulo MFV, Magalhães FJR, Filho CDFL, Oliveira S, Soares HS, Feitosa TF, Aizawa J, Alves LC, Mota RA, Dubey JP, Gennari SM, Pena HFJ. 2017. Cat-rodent Toxoplasma gondii Type II-variant circulation and limited genetic diversity on the Island of Fernando de Noronha, Brazil. Parasites \& Vectors, 10(1), 220.

73. Silva RC, Souza LC, Langoni H, Tanaka EM, Lima VY, Silva AV. 2010. Risk factors and presence of antibodies to Toxoplasma gondii in dogs from the coast of São Paulo State, Brazil. Pesquisa Veterinária Brasileira, 30(2), 161-166.
74. Smith KE, Zimmerman JJ, Patton S, Beran GW, Hill HT. 1992. The epidemiology of toxoplasmosis on Iowa wine farms with an emphasis on the roles of free-living mammals. Veterinary Parasitology, 42(3-4), 199-211.

75. Souza LZ, Rodrigues RGA, Oliveira DAD, Roman JL, Pinto SB, Bittencourt LHFB, Oyafuso MK. 2017. Soroprevalência de Toxoplasma gondii em gatos domiciliados em Palotina, Paraná, Brasil. Arquivos de Ciências Veterinárias e Zoologia da UNIPAR, Umuarama, 20(3), 123-126.

76. Souza SF, Medeiros LS, Belfort AS, Cordeiro ALL, Federle M, Souza AP, Moura AB. 2015. Toxoplasma gondii antibodies in domiciled cats from Rio Branco Municipality, Acre State, Brazil. Semina: Ciências Agrárias, Londrina, 36(6), 3757-3762.

77. Souza SL, Gennari SM, Yai LE, D'Auria SR, Cardoso SM, Junior JSG, Dubey JP. 2003. Occurrence of Toxoplasma gondii antibodies in sera from dogs of the urban and rural areas from Brazil. Revista Brasileira de Parasitologia Veterinária, 12(1), 1-3.

78. Strang AG, Ferrari RG, do Rosário DK, Nishi L, Evangelista FF, Santana PL, de Souza AH, Mantelo FM, Guilherme ALF. 2020. The congenital toxoplasmosis burden in Brazil: systematic review and meta analysis. Acta Tropica, 211, 105608.

79. Strital AD, Igarashi M, Muraro LS, Aguiar DM, Pacheco TA, Garcia JL, Freitas SH, Amude AM. 2016. Estudo epidemiológico e avaliação de fatores de risco da infecção por Toxoplasma gondii e achados clínico-patológicos da infecção aguda em cães admitidos em um Hospital Escola Veterinário. Pesquisa Veterinária Brasileira, 36(10), 993-998.

80. Subsecretaria de Vigilância, Fiscalização Sanitária e Controle de Zoonoses. 2017. Histórico - Instituto Jorge Vaistman. http:// www0.rio.rj.gov.br/ijv/historico.shtm. Accessed 23 May 2017.

81. Teixeira JV, Oliveira JLS, Almeida DMPF, Gonçalves LS, Oliveira FLL. 2016. Seroprevalence of feline toxoplasmosis in Teresina, Piauí, Brazil. Revista Brasileira de Higiene e Sanidade Animal, 10(4), 549-555.

82. Tenter AM, Heckeroth AR, Weiss LM. 2000. Toxoplasma gondii: from animals to humans. International Journal for Parasitology, 30, 1217-1258.

83. Troncoso Toro IE, Uribe Henríquez PA, Arrué Brenet KC, Valenzuela Contreras AA, Fischer Wiethuchter C. 2015. Seroprevalencia de Toxoplasma gondii en gatos (Felis catus, Linnaeus 1758) residentes en San Carlos, Chile. Revista de Medicina Veterinaria, 29, 23-31.

84. Ullmann LS, Guimarães FF, Fornazari F, Tomé RO, Camossi LG, Greca H, Silva CR, Menozzi BD, Langoni H. 2008. Ações de vigilância continuada, papel do cão como animal sentinela para toxoplasmose. Revista Brasileira de Parasitologia Veterinária, Jaboticabal, 17(Suppl. 1), 345-347.

85. Yilmaz SM, Hopkins SH. 1972. Effects of different conditions on duration of infectivity of Toxoplasma gondii oocysts. Journal of Parasitology, 58(5), 938-939.

86. Zarra-Nezhad F, Borujeni MP, Mosallanejad B, Hamidinejat H. 2017. A seroepidemiological survey of Toxoplasma gondii infection in referred dogs to Veterinary Hospital of Ahvaz, Iran. International Journal of Veterinary Science and Medicine, 5(2), $148-151$.

Cite this article as: Arruda IF, Millar PR, da Barbosa A, de Souza Abboud LC, dos Reis IC, da Cruz Moreira AS, de Paula Guimarães MP \& Amendoeira MRR. 2021. Toxoplasma gondii in domiciled dogs and cats in urban areas of Brazil: risk factors and spatial distribution. Parasite 28, 56. 
An international open-access, peer-reviewed, online journal publishing high quality papers on all aspects of human and animal parasitology

Reviews, articles and short notes may be submitted. Fields include, but are not limited to: general, medical and veterinary parasitology; morphology, including ultrastructure; parasite systematics, including entomology, acarology, helminthology and protistology, and molecular analyses; molecular biology and biochemistry; immunology of parasitic diseases; host-parasite relationships; ecology and life history of parasites; epidemiology; therapeutics; new diagnostic tools.

All papers in Parasite are published in English. Manuscripts should have a broad interest and must not have been published or submitted elsewhere. No limit is imposed on the length of manuscripts.

Parasite (open-access) continues Parasite (print and online editions, 1994-2012) and Annales de Parasitologie Humaine et Comparée (1923-1993) and is the official journal of the Société Française de Parasitologie. 